\title{
미국 ODA와 해외공관의 역할
}

\section{1. 원조정책 수립관련 공관의 역할}

ㅁ 매년 공관은 관할국에 대한 원조지원 전략 보고서

를 작성, 본부에 보고(회계년도 시작 20개월 전)

- USAID 해외주재 사무소(Mission)는 자신의 지

원전략을 대사에 보고하고, 대사는 USAID,

MCA(Millenium Challenge Account), 국방무

관의 원조전략 등을 모두 포함한 전체 원조전략

보고서를 본부에 보고

- 동 전략보고서에는 원조의 목적, 특정 지원사업

선정 및 3 개년 이행 계획, 예산 필요액 및 근거, 추진 프로그램의 구체사항 등을 기술

USAID 본부 등 각 해당부서는 각국 대사의 보고 서를 종합, 전체 원조계획안을 작성하고 예산을 신청하며, 할당된 예산에 따라 원조사업 실행

\section{2. 공관내 협의체 구성 여부}

몁의체라든가 $\mathrm{T} / \mathrm{F}$ 같은 공식적인 조직은 없으나, 공관내 경제참사관과 USAID간 수시 협의 진행,
전략목표 설정 및 특정사업 선정 등 관련 논의

3. 원조집행 및 감독, 사후관리 과정에서의 공관 의 역할

ㅁ 공관 및 주재대사는 주로 원조정책 수립과정에서 깊이 관여하며, 특별한 상황이 없는 한 원조집행 이라든가 감독, 사후관리 과정에는 거의 관여하지 않는 것이 관행

\section{4. 공관장에 대한 예산집행 재량권 부여 여부} ㅁ 미미한 수준(약 5천불 1만불 정도)이지만 재량권 이 있으며, 해당국에 따라 재량권 행사 액수에 다 소 차이가 있음.

ㄷ 다만, 자연재해 등 발생시 긴급구호와 관련해서는 공관장이 본부에 긴급청훈을 통해 일차로 $5 \sim 10$ 만 불 정도의 구호금을 신속히 승인받을 수 있는 시 스템을 갖추고 있음.

[자료:주미국 대사관] 